ISSN: 2414-0325. Open educational e-environment of modern University, special edition (2019)

\title{
УДК: 378.011.3:004]-051
}

\section{Кіржа Надія Василівна}

аспірант кафедри інноваційних та інформаційних технологій в освіті

Вінницького державного педагогічного університету імені Михайла Коцюбинського

викладач української мови та зарубіжної літератури

Вінницького медичного коледжу ім. акад. Д. К. Заболотного, Вінниця, Україна

800258@ukr.net

\section{ПОНЯТТЯ ПРОЕКТУВАЛЬНОЇ КОМПЕТЕНТНОСТІ В УМОВАХ ОСВІТНЬО-ІНФОРМАЦІЙНОГО СЕРЕДОВИЩА МЕДИЧНИХ КОЛЕДЖІВ}

\begin{abstract}
Анотація. У даній статті з'ясовано першочергові завдання розвитку освіти в Україні на 20122021 роки. Встановлено, що до першочергових завдань зараховують формування сучасного матеріально-технічного забезпечення освітньої галузі, підтримку розвитку електронного інструментарію освіти, втілення ІКТ-підготовки педагогів, тобто, в цілому, забезпечення необхідних передумов модернізації освітньої системи на інноваційній технологічній базі. Виділено протиріччя у сфері потенційних можливостей збільшення ефективності навчального процесу на практиці. Визначено, що освітньо-інформаційним середовищем можемо назвати розподілену за територіальним і рівневим принципом конструкцію опанування інформаційно-освітніх просторів, яка має на меті створити умови, сприятливі для виникнення і прогресу в процесах освітньо-мережевих взаємозв'язків між об'єктами та суб'єктами середовища, а також формувати активність об'єктів, спонукати освітні та соціальні ініціативи для того, щоб компетентність розвивалася як значуща цінність як для суспільства, так і для особистості. З'ясовано, що застосування поетапної інтеграції ОІС, може сприяти природному формуванню i розвитку освітньо-інформаційного середовища із безпосередньою участю викладацького складу. При цьому, концептуальна каскадноциклічна структурна схема демонструє систему взаємозв'язків між кожним із основних елементів (етапів) цього процесу. Визначено чинники, що спричинили суттєве розширення сфери застосування електронного ресурсу у навчальному процесі. Виявлено ряд проектувальних умінь, необхідних для формування у педагога проектувальної компетентності, до структури якої входять знання, уміння та професійно значимі якості особистості, необхідні для здійснення проектувальної діяльності. Визначено вимоги до організації та підготовки студентів медичних коледжів до розробки електронних освітніх ресурсів. З'ясовано, що впровадження в освітній процес новітніх інформаційнокомунікаційних технологій призвело до суттєвих змін у системі дидактичних засобів. Доведено, що мобільність визначає успішність кожного з випускників за умов цифрового і технологізованого суспільства, можливість ефективної співпраці, розв'язування завдань, креативно підходити до навчання та дослідницької діяльності та ін.
\end{abstract}

Ключові слова: компетентність; комунікація; комунікативна компетентність; медичний коледж; студенти; проектувальна компетентність; освітньо-інформаційне середовище

Постановка проблеми. Невід'ємними компонентами освітньої галузі, що оптимізують і підвищують ії ефективність, є інформаційні технології. Національною стратегією розвитку освіти в Україні на 2012-2021 роки визначено, що пріоритетом для розвитку освітньої галузі є запровадження новітніх технологічних засобів інформаційнокомунікаційного характеру до навчального процесу. До першочергових завдань зараховують формування сучасного матеріально-технічного забезпечення освітньої галузі, підтримку розвитку електронного інструментарію освіти, втілення ІКТпідготовки педагогів, тобто, в цілому, забезпечення необхідних передумов модернізації освітньої системи на інноваційній технологічній базі.

Аналіз останніх досліджень та публікацій. Питанням комунікативної компетентності присвячували свої праці такі провідні науковці, як: Данилова О. В., Деркач Т. М., Маричева Л. Е., Олефіренко Н. В., Роберт I. В., Чернобай С. В. та інші. 
Проте сучасна наука потребує дослідження особливостей використання Інтернет ресурсів для формування комунікативної компетентності студентів медичних коледжів.

Мета статті - з'ясувати особливості формування проектувальної компетентності в умовах освітньо-інформаційного середовища медичних коледжів.

Виклад основного матеріалу. Пріоритетним напрямом підготовки студентів медичних коледжів залишається впровадження освітньо-інформаційного середовища (OIC) у навчальний процес. Незаперечними перевагами OIC $є$ полегшення розуміння та засвоєння знань, можливість візуалізації інформації, автоматизація процесів обчислювальної діяльності, створення умов для самостійної роботи студентів. Впровадження ОIC гальмується слабкою розробленістю дидактичних основ та відсутністю науково обгрунтованих практичних рекомендацій щодо застосування їх у вищому навчальному закладі. Темпи розвитку інформаційних технологій випереджають процеси психолого-педагогічного осмислення наслідків їх упровадження, a реорганізація традиційних форм навчання на базі інформаційно-комунікаційних технологій (IКТ) наражається на відсутність у викладачів готовності до цього та відповідних умінь. Потенційні можливості збільшення ефективності навчального процесу на практиці реалізується далеко не повністю (Деркач, 2014). Отже, можемо виокремити кілька протиріч:

- між необхідністю вдосконалити організацію та посилити роль самостійного розвитку пересічного студента і невмінням використовувати для цього інформаційнокомунікаційні технології;

- між змогою організувати особистісно-орієнтовний та диференційований навчальний процес із використанням ІКТ та браком методичних напрацювань у цьому питанні;

- можливості студентства, яке в більшості своїй освоїло прийоми трудової діяльності в сучасному інформаційному середовищі, суперечать методам, засобам й організаційним формам навчального процесу, пропонованим у решті освітніх установ;

- наявні програмні засоби розроблені українськими вищими навчальними закладами, проте відсутня їх систематизація і стандартизація, що ускладнює обмін досвідом, а також наявна нестача теоретичних та методичних напрацювань щодо того, як застосовувати програмні продукти, щоб формувалися професійні знання у тих, хто опановує спеціальності.

Таким чином, освітньо-інформаційним середовищем можемо назвати за розподілену територіальним i рівневим принципом конструкцію опанування інформаційно-освітніх просторів, яка має на меті створити умови, сприятливі для виникнення і прогресу в процесах освітньо-мережевих взаємозв'язків між об'єктами та суб'єктами середовища, а також формувати активність об'єктів, спонукати освітні та соціальні ініціативи до того, щоб компетентність розвивалася як значуща цінність як для суспільства, так і для особистості.

Ефективно застосувати ОІС в навчанні можна у разі обгрунтованого і гармонійного інтегрування відповідних навчальних технологій у освітню систему, збагачування педагогічних технологій, полегшення вирішення управлінських задач, а завдяки накопиченим в освітній системі досвіду, знанням, традиціям поповниться змістова, загальнокультурна складова в інформаційному просторі - між науково-методичною лабораторією конкретного ВНЗ та глобальною мережею Інтернет. Системна інтеграція OІC повинна включати всі види структур ВНЗ (навчальних, наукових, адміністративних) і супроводжувати вирішення таких завдань:

- адаптувати самі структури і вже існуючі освітні технології до можливого запровадження у ОIC; 
- пристосувати технології до вимог, пред'явлених кожною з цих структур;

- створити взаємокореляційні структури відповідно до ОІС.

Застосовуючи поетапну інтеграцію ОІС, можна сприяти природному формуванню i розвитку освітньо-інформаційного середовища із безпосередньою участю викладацького складу. Концептуальна каскадно-циклічна структурна схема демонструє систему взаємозв'язків між кожним із основних елементів (етапів) цього процесу.

Під час першого етапу визначають мету та фіксують потребу й можливість використовувати ОІС в освітній системі. Приводом для того, щоб ініціювати інтеграцію, $\epsilon$ повний контроль викладачем освітньо-інформаційного процесу у межах усіх навчальних дисциплін. Система структурованих навчально-методичних матеріалів стає підгрунтям для створення ОIC і використовується викладачем під час навчального процесу.

Наступний етап полягає в прогностичному аналізі. Використовуючи ОIC, з'ясовують основні проблемні питання стосовно уточнення та прогнозування дисциплін, а саме аналізують наявну вихідну інформацію, оцінюють стан використання навчальної системи, уточнюють напрямки запровадження (конкретні дисципліни, цикли, модулі таке ін.). Цей етап складається із трьох стадій. Перша, згідно з головною метою, полягає у всебічному гармонійному розвиткові кожного студента, зумовлює готовність самореалізуватися, коли відбувається визначення основних завдань у вивченні дисциплін. Застосовуючи ОIC, можна істотно вплинути на те, як вони формуються, оскільки з'являється змога розширення або зміни змісту досліджуваної дисципліни, посилення вимог до якісного рівня у навчанні та особистісного прогресу студентів. Друга стадія вимагає аналізувати детальну програму, форму навчального заняття, особливості взаємин між студентами і викладачем, критерії і методи оцінювання. У межах третьої аналізують і оцінюють такі характеристики, як: спеціалізацію студентів, здатність самостійно здійснювати пошуково-дослідницьку роботу, їх мотивацію у досліджуваній дисципліні і загальнопрофесійній підготовці загалом. Зрештою, можна проаналізувати й оцінити готову навчальну систему, щоб визначити, наскільки вона відповідає низці нових цілей і завдань, поставлених вже у темі використання ОIC.

Не завжди викладач отримує змогу вибрати засоби ОIC. Інколи у вищому навчальному закладі наявний передбачений існуючими програмними засобами чіткий перелік умов їхнього застосування під час навчального процесу (стосується, приміром, систем автоматизованого тестування та ін.). Через це $є$ потреба адаптувати те, як викладачі використовують освітні технології у ОІС. Однак одночасно із цим процесом здійснюється цілеспрямований вибір таких IКТ, що найкраще допомагають вирішувати педагогічні проблеми. На цьому етапі реалізується стратегія оптимального вибору, яка потребує:

1) визначити цілі, які можна реалізувати, використовуючи ОІС (активізація пізнання, розвиток таких якостей, як: логічне мислення, креативність, комунікабельність, мобільність та ін.);

2) визначити 3-поміж наявних IKT ті, що допомагають досягти найкращих результатів, реалізуючи ці цілі;

3) обрати технології, чия інтеграція до сформованої структури освітньої системи буде найбільш природною.

Тож викладачем здійснюються конструювання інтегративного рішення, визначального для специфіки навчально-виховного процесу.

Під час наступного етапу проектують інтеграцію OIC та детально координують весь освітній процес. Перш за все, формують інформаційну мету - забезпечити явні посилання на впроваджені ресурси до навчальних програм, курсів, лекцій та в іншу 
навчально-методичну документацію. Щоб ефективно використовувати ресурси ОIC, варто нерозривно поєднати їх i традиційні навчально-методичні матеріали, використовуючи взаємні посилання. Ураховуючи змістові перетворення у досліджуваній дисципліні, нові пропорції між аудиторним та самостійними видами робіт, здійснюється внесення відповідних тематичних змін у лекції, семінари та ін. Щоб забезпечити продуктивну самостійну роботу студентства, готується ряд спеціальних завдань у супроводі тренувальних програм або тестів, моделюючих програм тощо.

Для того, щоб практично реалізувати проект, необхідно попередньо оновити навчально-методичну документацію, необхідну у навчанні із застосуванням вибраного виду технології, попередньо протестувати програмне забезпечення, провести додаткову комп'ютерну підготовку викладацького складу і студентства.

Успішність інтегрування визначається за допомогою основного критерію: те, наскільки вдалося реалізувати нові цілі і завдання, поставлені у питанні використання OIC. Завдяки моніторингу навчального процесу можна дізнатися, якого саме втручання він потребує, щоб краще його адаптувати. 3 цією метою вдаються до педагогічних дослідницьких методів (анкетування, спостереження, бесіди), що дозволяє викладачу скласти оперативну оцінку ефективності інновації. Керувати навчальним процесом означає безперервно вивчати, як відбувається навчання, які ІКТ використовуються та як скорегувати процес. У разі виявлених серйозних недоліків $\epsilon$ потреба додатково проаналізувати і доопрацювати інтеграції IКТ в ОIC.

Протягом завершального етапу вивчають наявні здобутки. Щоб оцінити результати, застосовують дослідницькі методики з контрольними і експериментальними групами. Таке дослідження повинно бути спланованим, адже воно потребує значних ресурсів. В інших випадках $є$ ряд неформальних методів, які використовує у своїй практичній діяльності велика кількість педагогів. Враження, отримані викладачем у спілкуванні зі студентами, наявність у них активності і творчого підходу під час самостійної роботи, позитивних відгуків або, навпаки, недостатній зворотній зв'язок, демонстрація пасивності, роз'єднаності, незадоволеності студентів навчальним процесом та його результативністю. Найбільшої об'єктивності можна домогтися, комплексно проаналізувавши навчальний процес, індивідуально-особистісний розвиток, соціальну адаптацію, психологічний стан студентів та якісні показники цих явищ. Структурна схема використання ОIC у освітньому процесі ВНЗ завершується і замикається на аналізі результатів. Це дозволяє переосмислити наявні проблеми, знайти спосіб вдосконалення за допомогою зворотного зв'язку.

Розглянутому процесу введення OIC у навчальну систему не притаманна лінійність. Завдяки викладеній послідовності кроків, з'являється основа для практичної реалізації, можливо, більш складної схеми. На більшості етапів процесу є необхідність перегляду попередніх рішень. Наявність такої циклічності - природний, навіть позитивний момент у структурній схемі, що додає навчальному процесу повноти та $є$ відображенням його рекурсивної природи.

Виходячи 3 цього, можна сказати про властиві освітньому середовищу різнобічність можливостей: ОIC сприяє цілісному творчому процесу шляхом надання ресурсів, необхідних для втілення задумів, і навчальних засобів, а також відіграє роль певного каталізатора для виявлення своїх можливостей, якщо організація освітнього процесу зазнає певних змін. Теоретична описова інформація надається в електронному варіанті. Під час лекцій, в основному, обговорюють проблемні питання, а під час семінарів та практичних занять педагог дає студенту завдання творчого характеру, щоб націлити його на пошуково-дослідницьке пізнання, у процесі якого навчаються не лише використовувати алгоритми рішень задач експертного та винахідницького типу, а i 
вдосконалювати ОІС ВНЗ. Разом із цим викладач вдається до методик, націлених активізувати пізнавальну діяльність: мозкового штурму, синектики, морфологічного аналізу тощо у форматі «віртуальний семінар», що дає шанс розкрити свій потенціал усім, хто навчається.

Такий процес, як інформатизація охопив усі освітні щаблі. Суттєве розширення сфери застосування електронного ресурсу у навчальному процесі було спричинено рядом чинників, серед яких:

1) насичення побутового життя молодих людей великою кількістю цифрових пристроїв, що зумовило прихід до вищих навчальних закладів абітурієнтів, що мають сформовані користувацькі навички;

2) налаштування студентської аудиторії на сприймання візуальних наочних матеріалів, наприклад, з комп'ютерів;

3) створення безпечніших електронних пристроїв для навчання, що вирішує проблеми, пов'язані зі шкідливим впливом їх на самопочуття користувачів;

4) потужний фонд багатофункціонального електронного ресурсу, що розрахований на вивчення різноманітних предметів (хімія, фізика, мова, історія, біологія, географія, інформатика, культурологія та ін.);

5) зацікавлення студентів у напрацюванні навичок впевненого користувача комп'ютерною технікою для вирішення різних задач, зокрема, фахових, прикладних та навчально-пізнавальних;

6) підвищення сучасних суспільних вимог щодо якісного рівня освіти, що потребують ії оновлення на інформаційно-комунікаційній технологічній основі.

Разом із цим, впровадження електронних технологій у навчальний процес має свою специфіку: воно вимагає від педагогів обгрунтованого, чіткого планування, виваженого та обережного вибору інструментарію як з погляду перспективи досягнення поставлених дидактичних цілей, так і з погляду того, якими є індивідуальні навчальні можливості і потреби студентської аудиторії. Це спричиняє самостійно створювати дидактичні електронні ресурси та обирати зі спектру інструментарію, що надає педагогічним працівникам, які не мають професійної інформаційно-технологічної підготовки, можливість створювати дидактичні електронні ресурси для забезпечення конкретних навчальних цілей. Для викладачів це нова і складна діяльність, що вимагає спеціальних знань психолого-педагогічного, методичного, технологічного і ергономічного характеру, вміння забезпечити збереження здоров'я (санітарно-гігієнічні норми щодо устаткування, режим роботи із комп'ютерною технікою та ін.). Це спричиняє потребу запровадити низку обгрунтованих процедур по підготовці викладачів до роботи 3 електронним обладнанням.

Розвиток вищої школи в Україні, створення нової освітньої моделі вимагає грунтовного аналізу і переосмислення теоретико-методичного i концептуального підготовчого напряму майбутніх спеціалістів, його модернізації, не виключенням $\epsilon$ студенти медичних коледжів.

Суспільний попит на якісну вищу освіту, передумови професійної роботи викладачів, які відповідають сучасному рівневі розвитку, що пов'язуються 3 різноманітними освітніми системами, варіативним змістовим наповненням освітньої, технічної та технологічної бази навчання, розширенням спектру застосування таких технологічних засобів у навчальному процесі студентів й необхідним передбаченням результатів професійного планування, способами забезпечення очікуваного результату, аналізом й оцінкою прийнятих та можливих рішень - усе це вимагає зростання важливості проектування як складової роботи викладачів.

Науковці наголошують на тому, що педагоги повинні вміти здійснювати 
проектування власної діяльності та студентської діяльності на заняттях згідно з новими сучасними вимогами. За умов постійних суспільних змін суспільству необхідно передбачати майбутне шляхом врахування особливостей і темпу його технологічної i соціально-економічної динаміки. Як вважає Г. Є. Муравйова, проектування технологічного наповнення навчальної діяльності повинно бути основою планувальної роботи педагога щодо організації та керування навчальним процесом.

Л. Є. Маричева вважає необхідним формування у педагога проектувальної компетентності, до структури якої входять знання, уміння та професійно значимі якості особистості, необхідні для здійснення проектувальної діяльності (Маричева, 2008, с. 37). До проектувальних умінь дослідниця включає широке коло умінь:

- аналізувати дані, конкретизувати освітні цілі;

- відбирати матеріал відповідно до поставлених цілей і задач;

- представляти навчальний матеріал у вигляді моделей діяльності студента;

- співвідносити представлену модель діяльності з досвідом життєдіяльності студента;

- виокремлювати можливі технологічні способи навчання й співвідносити їх 3 дидактичною метою, методами, засобами й формами організації навчання, методичними особливостями теми, навчальними можливостями студента;

- розробляти кілька варіантів процедур навчально-пізнавалної діяльності студентів в процесі їх просування на більш високий рівень;

- оцінювати й порівнювати варіанти структури діяльності студентів, вибирати оптимальний варіант;

- розробляти мотиваційні й особистісно-розвиваючі ситуації;

- визначати структуру діяльності викладача відповідно до структури навчальнопізнавальної діяльності студента;

- підбирати наочні посібники, роздатковий матеріал, аудіовізуальні матеріали;

- оцінювати способи використання зовнішніх умов освітнього процесу;

- здійснювати корекцію структури освітнього процесу;

- розподіляти час кожного етапу в освітньому процесі;

- фіксувати проект освітнього процесу у вигляді документа у письмовій або графічній формі (Маричева, 2008, с. 37).

На основі аналізу існуючої системи підготовки педагога О.В.Чернобай зазначає, що проектування навчального процесу в інформаційному середовищі передбачає відбір і структурування змісту, обгрунтування рівнів його засвоєння, відбір видів навчальної діяльності, методів, організаційних форм і засобів навчання для реалізації педагогічних цілей, конструювання навчальних ситуацій (Чернобай, 2012).

О. В. Даниловою визначені вимоги до організації та підготовки студентів медичних коледжів до розробки електронних освітніх ресурсів:

- наступність підготовки - взаємозв'язок змісту підготовки з розробкою електронних ресурсів 3 програмами підготовки 3 інформатики та IKT, а також 3 спеціальними дисциплінами;

- прогностичність підготовки, тобто відображення в програмах прогнозу результатів сучасних досягнень;

- спільність підходів до розробки електронних освітніх ресурсів, тобто реалізація послідовності етапів;

- $\quad$ фундаментальність й практична направленість підготовки, яка передбачає висвітлення теоретичних питань та питань, спрямованих на рішення практичних педагогічних задач щодо технології розробки електронних освітніх ресурсів за 
допомогою прикладних й інструментальних програмних засобів;

- інваріантність й варіативність підготовки, тобто виявлення базового змісту підготовки для студентів всіх напрямів підготовки;

- організація підготовки, що відображає особливості розробки електронних ресурсів конкретної предметної галузі (Данилова, 2010, с. 18-19).

Розвиток інформаційних технологій, поява нових потужних можливостей програмних засобів для забезпечення різних етапів навчання зумовило появу значного арсеналу педагогічних програмних засобів - електронних посібників та підручників, електронних конспектів лекцій, робочих зошитів та задачників, мультимедійних лекції, тренажерів, контролюючих систем, предметних середовищ, енциклопедій та довідників тощо, кожен з яких має свої функції та особливості. Впровадження в освітній процес новітніх інформаційно-комунікаційних технологій призвело до суттєвих змін у системі дидактичних засобів:

1) традиційні друковані засоби навчання (навчальні підручники, посібники, робочі зошити тощо) поступово витісняються електронними. Змінилася не тільки форма зберігання навчальної інформації, відбулися якісні зміни у сутності та структурі засобів навчання. Сучасні електронні дидактичні засоби вже не можуть бути зведені до друкованих видань без втрати їх функціональності;

2) змінилася якість ілюстративного матеріалу, який використовується для демонстрації тих чи інших теоретичних положень. Сучасні репродукції, фотографії, графічні зображення, відеоматеріали, які зберігаються у цифровому форматі, створюють ілюзію присутності, дозоляють студентам розглянути об'єкт у різних ракурсах і при цьому не втрачають своєї якості при багаторазовому використанні. Педагог отримав можливість самостійно створювати ілюстративний матеріал відповідно до потреб конкретного заняття. Змінилася якість засобів схематичного подання інформації (схем, таблиць, графіків);

3) змінився відсоток дидактичних засобів, які викладач самостійно створює для потреб конкретного заняття. Під час підготовки необхідних для заняття дидактичних засобів викладач може скористатися сучасними цифровими пристроями: відео- та фотокамерами, аудіопристроями, готовими фрагментами наявних дидактичних ресурсів, програмними засобами, які надають можливість швидко виокремити, відредагувати та скомпонувати потрібні фрагменти зображень, відеозаписів, презентацій, електронних курсів тощо;

4) змінився інструментарій для проведення експериментальних досліджень. Лабораторне устаткування, підключене до комп'ютера, надає нові можливості для здійснення реальних експериментів у межах медколеджу; стало можливим використовувати віртуальні «лабораторії», експеримент наблизився до реального наукового дослідження;

5) змінилися засоби подання і відтворення інформації. Педагог отримав можливість скористатися новим інструментарієм, технічними пристроями для відтворення інформації в електронній формі (проекторами, інтерактивними дошками, документрідерами тощо) та програмними засобами: віртуальними дошками, картами знань тощо.

Зміни, що відбулися у системі дидактичних засобів, різноманіття підтипів, що зумовлені різним функціональним призначенням дидактичних засобів приводять, 3 одного боку, до складної схеми, а з іншого, до їх дублювання по відношенню до інших засобів навчання. У зв'язку з цим вважаємо доцільним виокремити типи дидактичних засобів за їх функціональним призначенням для будь-якої форми їх подання або зберігання і визначити місце дидактичних електронних ресурсів у системі засобів 
навчання. Так, систему дидактичних засобів можна подати у вигляді чотирьох груп:

1) Дидактичні засоби, що є джерелами інформації:

1.1) об'єкти навколишньої дійсності в їх природному стані;

1.2) моделі об'єктів навколишньої дійсності: матеріальні-муляжі, зменшені копії об'єктів тощо; образні (незалежно від форми їх зберігання) -малюнки, ілюстрації, фотознімки, відео- та аудіозаписи; вербальні -усний опис об'єкту, озвучені тексти; знакові - схеми, креслення, хімічні формули, мапи; віртуальні - аналоги реальних або абстрактних об'єктів у віртуальному середовищі; виклад відомостей (знань) про об'єкт (незалежно від форми подання) - довідники, енциклопедії, підручники, посібники (електронні і друковані), мультимедійні презентації, навчальні кінофільми, аудіо- та відеоуроки тощо;

2) дидактичні засоби для організації засвоєння навчального матеріалу;

3) дидактичні засоби для здійснення контролю й діагностики навчального процесу: засоби автоматизованого тестування; тести; електронні задачники;

4) дидактичні засоби для дослідження, створення та відтворення джерел інформації: а) інструменти для створення моделей об'єктів - аудіопристрої, фото-, відеота вебкамери; програмні засоби для створення образних, знакових моделей об'єктів: ментальні карти, віртуальні дошки; б) інструменти для створення та редагування засобів, призначених для викладу відомостей та організації засвоєння навчального матеріалум відеоуроків, електронних курсів, електронних підручників, посібників тощо; в) інструменти для відтворення джерел інформації: комп'ютер, відеопрогравач, магнітофон, проектор, лінгафонне обладнання, віртуальна дошка, інтерактивна дошка тощо; г) інструменти для дослідження об'єкту: мікроскоп, телескоп, вимірювальні інструменти, навчальні лабораторні комплекси, в тому числі і комп'ютерні; д) інструменти для створення і дослідження віртуальних моделей об'єктів: віртуальні лабораторії (хімічні, фізичні) тощо (Олефіренко, 2014, с. 30, 44-45, 47-48).

Проведений аналіз дає змогу зробити висновок, що динаміка інформаційнокомунікаційного ресурсу стимулювала значне розширення дидактичного інструментарію, що може бути використаний для досягнення навчальних цілей. Поява i розвиток таких засобів значно поповнила запас дидактичних інструментів, таких як: електронні навчальні посібники, електронні курси, мультимедійні засоби та ін.

На основі аналізу можливостей інформаційно-комунікаційних технологій I. В. Роберт, С. В. Панюкова, О. А. Кузнєцов, А. Ю. Кравцова визначають такі їх дидактичні функції: інформаційно-довідкову (за рахунок подання різного роду інформації, наочної демонстрації матеріалу й комп'ютерної візуалізації досліджуваного об'єкту та його складових частин); індивідуалізації й диференціації процесу засвоєння навчального матеріалу в ході занять та самостійної роботи студентів; оптимізації навчального процесу (за рахунок можливостей поетапної роботи або роботи в певному темпі); контролюючої (за рахунок здійснення об'єктивного контролю зі зворотним зв'язком, оцінювання знань, умінь і навичок, здійснення самоконтролю); коригуючої (за рахунок здійснення в процесі навчання консультацій та інших видів допомоги); діагностуючої (за рахунок інформування викладача про результати навчання); автоматизації процесів управління навчальною діяльністю при здійсненні реєстрації, збирання, аналізу, зберігання інформації про студентів, розсилання необхідного матеріалу та інформації по мережі; моделювання реальних дослідів, імітації роботи різноманітних лабораторних стендів, об'єктів, процесів і явищ; автоматизації процесів обробки результатів лабораторного експерименту, побудови графіків, таблиць і діаграм, отримання інформації про перебіг процесів і явищ реальності (Роберт, 2008, с. 54-55).

Н. В. Олефіренко визначені функції дидактичних електронних ресурсів. Перша 
група містить функції, що сприяють формуванню позитивного ставлення студента до процесу і результату навчання. До цієї групи віднесено функції: 1) розвитку власних мотивів студента до виконання навчальних дій, 2) відслідковування і схвалення успішних дій студента, 3) створення сприятливого емоційного фону, 4) реалізації зв'язку змісту навчання з життям. У другій групі зібрані функції, що забезпечують успішність студента у засвоєнні змісту навчання. До цієї групи віднесено функції: 1) візуалізації, 2) тренінгову, 3) корекції набутих знань й умінь, 4) інтеграційну, 5) адаптаційну, 6) забезпечення своєчасної допомоги в опануванні змісту навчання, 7) компенсаторну. Третю групу складають функції оптимізації навчального процесу, а саме функції: 1) контрольна, 2) діагностична; 3) моніторингова, 4) інтенсифікації навчального процесу. У четвертій групі об'єднані функції, зорієнтовані на закладання основ успішності подальшого навчання студента. Ця група включає функції, які є важливими для поточного навчального процесу, але мають перспективний характер i сприяють становленню пізнавальної діяльності студента. До цієї групи віднесено функції: 1) інструментальну, 2) дослідницьку, 3) розвитку інтелектуальних умінь, 4) мобілізаційну, 5) сприяння формуванню цілісного світогляду (Олефіренко, 2014, с.65).

Викладачем реалізується державна політика про освітню інформатизацію, здійснюючи підготовку студентів до життєдіяльності в межах інформаційного суспільства, де все швидше з'являються нові знання, що зумовлює потребу увесь час створювати нові професії та навчання. Мобільність визначає успішність кожного 3 випускників за умов цифрового і технологізованого суспільства, змогу ефективної співпраці, розв'язування завдань, креативно підходити до навчання та дослідницької діяльності та ін.

Теоретична та практична база може використовуватися педагогами вищої школи, що проводять підготовку за інформаційним, педагогічним та методичним напрямком для студентів, що $є$ майбутніми фахівцями, для модернізації змістового наповнення лекційного і практичного матеріалу, спецкурсів, створення методичної літератури; студентами під час здійснення завдань, що носять індивідуальний науково-дослідний характер, при написанні курсових, дипломних і магістерських робіт, у межах практики; викладачами післядипломного навчання під час таких напрямків роботи, як курсова перепідготовка та підвищування кваліфікаційного рівня.

Висновки, рекомендації, перспективи подальших досліджень. Освітньоінформаційним середовищем можемо назвати розподілену за територіальним і рівневим принципом конструкцію опанування інформаційно-освітніх просторів, яка має на меті створити умови, сприятливі для виникнення і прогресу в процесах освітньо-мережевих взаємозв'язків між об'єктами та суб'єктами середовища, а також формувати активність об'єктів, спонукати освітні та соціальні ініціативи для того, щоб компетентність розвивалася як значуща цінність як для суспільства, так і для особистості. Викладачем реалізується державна політика освітньої інформатизації шляхом здійснення підготовки студентів до життєдіяльності в межах інформаційного суспільства, де все швидше з'являються нові знання, що зумовлює потребу увесь час створювати нові професії та навчання. Мобільність визначає успішність кожного з випускників за умов цифрового і технологізованого суспільства, змогу ефективної співпраці, розв'язування завдань, креативно підходити до навчання та дослідницької діяльності та ін. Теоретична та практична база може використовуватися педагогами медичних коледжів, що проводять підготовку за інформаційним, педагогічним та методичним напрямком для студентів, що $\epsilon$ майбутніми фахівцями, для модернізації змістового наповнення лекційного i практичного матеріалу, спецкурсів, створення методичної літератури; студентами під час здійснення завдань, що носять індивідуальний науково-дослідний характер, при 
написанні курсових, дипломних і магістерських робіт, у межах практики; викладачами післядипломного навчання під час таких напрямків роботи, як курсова перепідготовка та підвищення кваліфікаційного рівня.

Перспективи подальших досліджень полягають у методологічних розробках системи дидактичних засобів, їх різноманітних підтипів, що зумовлені різним функціональним призначенням з метою активізації динамічного розвитку інформаційнокомунікаційного ресурсу студентів медичних коледжів.

\title{
СПИСОК ВИКОРИСТАННИХ ДЖЕРЕЛ
}

1. Данилова О. В. Подготовка студентов педагогического вуза к разработке электронных образовательных ресурсов: автореф. дис. канд. пед. наук: 13.00.08 «Теория и методика профессионального образования». Чебоксары, 2010. 22 с.

2. Деркач Т. М. Теоретичні та методичні основи підготовки майбутніх фахівців хімічних спеціальностей засобами інформаційних технологій: Автореф. дис. д-ра пед. наук : 13.00.04. Інститут вищої освіти. Київ, 2014. 40 с.

3. Марычева Л. Е. Теоретические основы проектировочной компетентности будущих учителей. Инновации в образовании. Вестник Нижегородского университета им. Н. Й. Лобачевского, 2008. № 6. С. 36-38.

4. Олефіренко Н. В. Підготовка майбутніх учителів початкової школи до проектування дидактичних електронних ресурсів : монографія. Х.: Вид-во ТОВ «Щедра садиба плюс», 2014. 336 с.

5. Роберт И. В. Информационные и коммуникационные технологии в образовании: учебно-методическое пособие; под ред. И. В. Роберт. М.: Дрофа, 2008. 312 с.

6. Чернобай Е. В. Методические основы підготовки учителей к проектированию ученого процесса в современной информационной образовательной среде (в системе дополнительного профессионального образования): автореф. дис. докт. пед. наук: спец. 13.00.02 «Теория и методика обучения и воспитания», 13.00.08 «Теория и методика профессионального образования». М., 2012. 50 с.

\section{THE CONCEPTS OF DESIGNING COMPETENCE IN THE CONDITIONS OF THE MEDICAL COLLEGE ENVIRONMENT}

\section{Nadiia Kirzha}

$\mathrm{PhD}$ (post graduate) student of the department of innovative and information technologies in education of Vinnytsia Mikhailo Kotsiubynskyi State Pedagogical University teacher of Ukrainian language and foreign literature of Vinnytsia D.K. Zabolotny Medical College, Vinnytsia, Ukraine 800258@ukr.net

\begin{abstract}
This article identifies the primary objectives of education development in Ukraine for 2012-2021. It is established that the formation of modern logistical support for the educational sector, support for the development of electronic educational tools, implementation of ICT training of teachers, ie, in general, providing the necessary prerequisites for the modernization of the education system on an innovative technological basis are among the top priorities. The contradictions in the field of potential opportunities for increasing the effectiveness of the educational process in practice are highlighted. It is determined that the educational and information environment can be called distributed on the territorial and level principle of the mastery of information and educational spaces, which aims to create conditions conducive to the emergence and progress in the processes of educational and network relationships between objects and entities environment, and to shape the activity of objects, to stimulate educational and social initiatives so that competence develops as a significant value for both society and the individual. It has been found out that the application of step-by-step integration of OIs can contribute to the natural formation and development of educational and information environment with the direct participation of teaching staff. In this case, the conceptual cascade-loop diagram illustrates the system of interconnections
\end{abstract}


between each of the main elements (stages) of this process. The factors that led to a significant expansion of the scope of electronic resource in the educational process have been identified. A number of designing skills necessary for the formation of a design competency in the teacher were identified, the structure of which includes the knowledge, skills and professionally significant personality qualities required for the design activity. The requirements for the organization and preparation of medical college students for the development of electronic educational resources are defined. It is found that the introduction of the latest information and communication technologies in the educational process has led to significant changes in the didactic system. It is proved that mobility determines the success of each of the graduates in the conditions of the digital and technological society, the possibility of effective cooperation, solving problems, creative approach to training and research activities, etc.

Keywords: competence; communication; communicative competence; medical college; students; design competence; educational and information environment

\section{REFERENCES (TRANSLATED AND TRANSLITERATED)}

1. Danylova, O.V. (2010). Preparing students of a pedagogical university for the development of electronic educational resources. Avtoref. dis. kand. ped. nauk: 13.00.08 «Teoriya I metodika professionalnogo obrazovaniya». Cheboksaryi, $22 \mathrm{p}$.

2. Derkach, T.M. (2014). Theoretical and methodological bases of preparation of future specialists of chemical specialties by means of in formation technologies. Avtoref. dys... d-raped. nauk: 13.00.04. Instytut v yshchoio svity. Kyiv, 40 p.

3. Maryicheva, L.E. (2008). The theoretical basis of the design competence off uture teachers. Innovation in education. Vestnik Nizhegorodskogo universiteta im. N. Y. Lobachevskogo, 6, 36-38.

4. Olefirenko, N.V. (2014). Preparation of future primary school teachers for the design of didactic electronic resources: monograph. Kharkiv: Vyd-vo TOV «Shchedrasadybaplius», $336 \mathrm{p}$.

5. Robert, I.V., Panyukova, S.V., Kuznetsov, A.A. \& Kravtsova, A. Yu. (2008). Information and communication technologies in education: a teach in gaid. Moskva: Drofa, $312 \mathrm{p}$.

6. Chernobay, E. V. (2012). Methodical foundation sof teacher training for the design of the educational processin a modernin for mation education alenvironment (in the system of additional professional education). Avtoref. dis. dokt. ped. nauk :spets. 13.00 .02 «Teoriya I metodika obucheniya I vospitaniya», 13.00.08 «Teoriya I metodika professionalnogo obrazovaniya» Moskva, $50 \mathrm{p}$. 